\title{
Muscarinic Receptor-Stimulated Phosphoinositide Turnover in Human SK-N-SH Neuroblastoma Cells: Differential Inhibition by Agents that Elevate Cyclic AMP
}

\author{
*Mayada Akil and †Stephen K. Fisher \\ Neuroscience Laboratory and Departments of ${ }^{*}$ Psychiatry and $\dagger$ Pharmacology, \\ University of Michigan, Ann Arbor, Michigan, U.S.A.
}

\begin{abstract}
The possibility that an increased intracellular concentration of cyclic AMP (cAMP) can regulate the extent of muscarinic receptor-stimulated phosphoinositide (PPI) turnover in the human neuroblastoma cell line SK-N-SH was examined. Addition of either forskolin (or its water-soluble analog, L-85,8051), theophylline, isobutylmethylxanthine, or cholera toxin, agents that interact with either the catalytic unit of adenylate cyclase, cAMP phosphodiesterase, or the guanine nucleotide binding protein linked to adenylate $\mathrm{cy}-$ clase activation, resulted in a $45-181 \%$ increase in cAMP concentration and a $27-70 \%$ inhibition of carbachol-stimulated inositol phosphate release. Through the use of digitoninpermeabilized cells, the site of inhibition was localized to a step at, or distal to, the guanine nucleotide binding protein
\end{abstract}

that regulates phospholipase $C$ activity. In contrast, when intact SK-N-SH cells were exposed to prostaglandin $E_{1}$, the ensuing increases in cAMP were not accompanied by an inhibition of stimulated PPI turnover. These differential effects of increased cAMP concentrations on stimulated PPI turnover may reflect the compartmentation of cAMP within SKN-SH cells. Key Words: Phosphoinositide-Cyclic AMPMuscarinic receptor-Human neuroblastoma, SK-N-SHForskolin-Cholera toxin. Akil M. and Fisher S. K. Muscarinic receptor-stimulated phosphoinositide turnover in human SK-N-SH neuroblastoma cells: Differential inhibition by agents that elevate cyclic AMP. J. Neurochem. 53, 14791486 (1989).
The hydrolysis of inositol lipids and regulation of adenylate cyclase activity constitute two of the major signal transduction pathways in both neural and nonneural cells. The possibility that cross-talk exists between these two signaling pathways has been suggested and evidence for cyclic AMP (cAMP)-mediated inhibition of stimulated phosphoinositide (PPI) hydrolysis has been obtained in some nonneural tissues (Nishizuka, 1986; Della Bianca et al., 1986; Jakobs et al., 1986; Neylon and Summers, 1988; Madison and Brown, 1988). However, little information exists to indicate whether a similar regulation of PPI turnover by cAMP also occurs in neural tissues.

In the present study, we have utilized the human neuroblastoma cell line SK-N-SH to determine whether elevated intracellular concentrations of cAMP result in an inhibition of receptor-stimulated PPI turnover. These cells appear well suited to such a study because they are homogeneous and possess receptors that are linked to the regulation of adenylate cyclase activity (Yu et al., 1986, 1988; Baron and Siegel, 1988). Furthermore, SK-N-SH neuroblastomata possess a high density of muscarinic cholinergic receptors (mAChRs) that are effectively coupled to PPI turnover, both in intact and permeabilized cells (Fisher and Snider, 1987; Fisher, 1988; Fisher et al., 1989). Our studies indicate that the addition of selective agents that elicit an increased intracellular concentration of cAMP independent of receptor activation also results in an inhibition of mAChR-stimulated PPI turnover in SK-N-SH cells.
Received January 6, 1989; revised manuscript received April 6, 1989; accepted April 12, 1989.

Address correspondence and reprint requests to Dr. S. K. Fisher at Neuroscience Laboratory, University of Michigan, $1103 \mathrm{E}$. Huron St., Ann Arbor, MI 48104-1687, U.S.A.

Abbreviations used: 8BcGMP, 8-bromo-cyclic GMP; cAMP, cyclic AMP; CT, cholera toxin; dBcAMP, 2-O-dibutyryl cyclic AMP; FSK, forskolin; $G_{i}$, inhibitory guanine nucleotide binding protein; $G_{p}$, guanine nucleotide binding protein that regulates phospholipase $\mathrm{C}$ activity; $\mathrm{G}_{\mathrm{s}}$, stimulatory guanine nucleotide binding protein;
GTP $\gamma \mathrm{S}$, guanosine-5'-O-(3-thiotriphosphate); IBMX, 3-isobutyl-Imethylxanthine; IP, inositol phosphate(s) (inositol mono-, bis-, tris-, and tetrakisphosphates); $\mathbf{I P}_{1}$, inositol monophosphate; L$85,8051,7 \beta$-deacetyl-7 $\beta$ - $(\gamma-N$-methylpiperazino)butyryl forskolin; mAChR, muscarinic acetylcholine receptor; NMS, $N$-methylscopolamine; $\mathrm{PGE}_{1}$, prostaglandin $\mathrm{E}_{1}$; $\mathrm{PPI}$, phosphoinositide (phosphatidylinositol, phosphatidylinositol 4-phosphate, and phosphatidylinositol 4,5-bisphosphate); SDS-PAGE, sodium dodecyl sulfate-polyacrylamide gel electrophoresis. 
Using digitonin-permeabilized cells, we demonstrate that the inhibition can be localized to a site that is either at, or distal to, the guanine nucleotide binding protein $\left(G_{p}\right)$ that regulates phospholipase $C$ activity. In marked contrast, prostaglandin $\mathrm{E}_{1}\left(\mathrm{PGE}_{1}\right)$-mediated increases in cAMP do not elicit an inhibition of stimulated PPI turnover, a result consistent with the possibility that the effects of cAMP on inositol lipid turnover are compartmentalized in SK-N-SH cells. A preliminary report of part of this work has appeared elsewhere (Akil and Fisher, 1988).

\section{MATERIALS AND METHODS}

myo- $\left[2-{ }^{3} \mathrm{H}\right]$ Inositol $(15 \mathrm{Ci} / \mathrm{mmol})$ was obtained from American Radiolabeled Chemicals (St. Louis, MO, U.S.A.). $N-\left[{ }^{3} \mathrm{H}\right]$ Methylscopolamine $\left(\left[{ }^{3} \mathrm{H}\right] \mathrm{NMS}\right)(80 \mathrm{Ci} / \mathrm{mmol})$ was obtained from New England Nuclear (Boston, MA, U.S.A.). Forskolin (FSK), 3-isobutyl-1-methylxanthine (IBMX), 2-Odibutyryl cyclic AMP (dBcAMP), theophylline, carbachol, and 8-bromo-cyclic GMP (8BcGMP) were obtained from Sigma Chemical (St. Louis, MO, U.S.A.). Guanosine 5'- $O$ (3-thiotriphosphate) (GTP $\gamma \mathrm{S})$ was purchased from Boehringer-Mannheim (Indianapolis, IN, U.S.A.). Cholera toxin (CT), 1,9-dideoxyforskolin, 7-O-hemisuccinyl-7-deacetyl forskolin, and $7 \beta$-deacetyl- $7 \beta-(\gamma-N$-methylpiperazino $)$ butyryl forskolin (L-85,8051) were obtained from Behring Diagnostics (La Jolla, CA, U.S.A.). Dowex-1 (100-200 mesh; $\times 8$ in the formate form) was obtained from Bio-Rad Laboratories (Rockville Center, NY, U.S.A.). Tissue culture supplies were obtained from Corning Glass Works (Corning, NY, U.S.A.). Powdered Dulbecco's modified medium and fetal bovine serum were purchased from Grand Island Biological (Grand Island, NY, U.S.A.). [ $\left.{ }^{32} \mathrm{P}\right] \mathrm{NAD}(39 \mathrm{Ci} / \mathrm{mmol})$ was obtained from New England Nuclear (Boston. MA, U.S.A.).

\section{Cell culture conditions}

Human SK-N-SH neuroblastoma cells were cultured in Dulbecco's modified Eagle's medium $/ 10 \%$ fetal calf serum in an atmosphere of $90 \%$ air $/ 10 \% \mathrm{CO}_{2}$ under conditions that have been described previously by Fisher and Snider (1987). Cells were first detached from tissue culture dishes by aspiration of the medium and the addition of $10 \mathrm{ml}$ of Puck's $D_{1}$ solution (Honegger and Richelson, 1976). They were then collected by centrifugation at $300 \mathrm{~g}$ for $1 \mathrm{~min}$ and resuspended in buffer $A(142 \mathrm{~m} M \mathrm{NaCl}, 5.5 \mathrm{~m} M \mathrm{KCl}, 2.2 \mathrm{mMCaCl}$, $3.6 \mathrm{mMNaHCO}, 1 \mathrm{mM} \mathrm{MgCl}, 5.6 \mathrm{mM}$ D-glucose, and 30 $\mathrm{m} M \mathrm{Na}^{+}$HEPES buffer, $\mathrm{pH}$ 7.4). Cells utilized were 10-20 days old. Protein determinations were performed by the method of Geiger and Bessman (1972).

\section{Determination of PPI turnover}

Intact SK-N-SH cells were harvested as described above. then resuspended in buffer $A$ containing $\left[{ }^{3} \mathrm{H}\right]$ inositol (approximately $9 \mu \mathrm{Ci} / \mathrm{ml}$ ) at a protein concentration of $0.8-2$ $\mathrm{mg} / \mathrm{ml}$ protein. Cells were first allowed to prelabel for $45 \mathrm{~min}$ at $37^{\circ} \mathrm{C}$, and then incubated (unless specified otherwise) for an additional $45 \mathrm{~min}$ in the presence or absence of carbachol $(10 \mathrm{mM}$ ), the various agents, and $10 \mathrm{mM} \mathrm{LiCl}$ (final volume, $0.5 \mathrm{ml}$ ). Reactions were terminated by the addition of $1.5 \mathrm{ml}$ of chloroform/methanol $(1: 2, \mathrm{vol} / \mathrm{vol})$ and the total watersoluble inositol phosphate (IP) fraction was separated and quantitated by ion-exchange chromatography as previously described by Fisher and Snider (1987). Both basal and car- bachol-stimulated release of ${ }^{3} \mathrm{H}$-IP was linear with time over a 45 -min incubation period. In other experiments, individual IP species were fractionated as previously described by Fisher and Bartus (1985) and Fisher et al. (1989). Approximately $75 \%$ of the label was recovered in inositol monophosphate $\left(\mathrm{IP}_{1}\right)$, with the remainder present in glycerophosphorylinositol, inositol bisphosphate, inositol trisphosphate, and inositol tetrakisphosphate. In some experiments, a 200- $\mu$ l aliquot was removed from the organic phase to determine the incorporation of $\left[{ }^{3} \mathrm{H}\right]$ inositol into the phospholipid fraction (Fisher and Bartus, 1985).

\section{Determination of intracellular cAMP levels}

SK-N-SH cells $(0.8-2 \mathrm{mg}$ protein $/ \mathrm{ml})$ were incubated with various agents for $45 \mathrm{~min}$ at $37^{\circ} \mathrm{C}$ (unless otherwise specified). Reactions were terminated by immersing the tubes in icecold water followed by centrifugation at $2,500 \mathrm{~g}$ for $3 \mathrm{~min}$. The supernatant was discarded, and the pellet extracted with $1 \mathrm{ml}$ of $7 \%$ perchloric acid. The extract was then neutralized with $\mathrm{K}_{2} \mathrm{CO}_{3}(1.77 \mathrm{M})$, dried down under $\mathrm{N}_{2}$, and resuspended in $50 \mathrm{~m} M$ sodium acetate buffer ( $\mathrm{pH}$ 6.2). cAMP quantitation was performed using a cAMP ${ }^{125}$ I radioimmunoassay kit from New England Nuclear (Boston, MA, U.S.A.). In most experiments, cAMP determinations were carried out on the same incubations utilized for PPI turnover measurement.

\section{CT treatment}

Intact cells. SK-N-SH cells were cultured in Dulbecco's modified Eagle's medium $/ 10 \%$ fetal calf serum containing $50 \mu \mathrm{g} / \mathrm{ml} \mathrm{CT}$ for 5 or $24 \mathrm{~h}$. Cells were then harvested, prelabeled with $\left[{ }^{3} \mathrm{H}\right]$ inositol for $60 \mathrm{~min}$, and incubated for 45 $\min$ at $37^{\circ} \mathrm{C}$ in the presence or absence of carbachol. The release of labeled IPs and/or cAMP concentrations determined were measured as described above.

Permeabilized cells. Cells were prelabeled for 3 days in medium containing $5-7.5 \mu \mathrm{Ci} / \mathrm{ml}$ of $\left[{ }^{3} \mathrm{H}\right]$ inositol. In one set of experiments CT was added to tissue culture dishes at a concentration of $50 \mu \mathrm{g} / \mathrm{ml}$ for an overnight incubation (approximately $16 \mathrm{~h}$ ). Cells were then harvested and permeabilized with digitonin as previously described by Fisher et al. (1989), prior to incubation with carbachol, GTP $\gamma$ S, or both for $15 \mathrm{~min}$ at $37^{\circ} \mathrm{C}$ and measurement of IP release. In a second series of experiments, prelabeled cells were first permeabilized, and then incubated with activated CT (Tamir and Gill, 1988) at a concentration $50 \mu \mathrm{g} / \mathrm{ml}$ for 30-60 $\mathrm{min}$. Release of labeled IPs was then measured following a 15min incubation with carbachol, GTP $\gamma \mathrm{S}$, or a combination of the two agents.

\section{ADP-ribosylation of SK-N-SH cells with $\Gamma^{32}$ PINAD and $C T$}

Control or CT-pretreated SK-N-SH cells were homogenized in $50 \mathrm{~m} M$ sodium phosphate buffer ( $\mathrm{pH} 7.4$ ) containing protease inhibitors $(10 \mu \mathrm{g} / \mathrm{ml}$ of leupeptin, aprotinin, and soybean trypsin inhibitor). Homogenates were then centrifuged at $500 \mathrm{~g} / 5 \mathrm{~min}$. pellets discarded, and supernatants centrifuged at $14,000 \mathrm{~g} / 10 \mathrm{~min}$. The pellets were then resuspended in $100 \mathrm{~m} M$ potassium phosphate buffer $(\mathrm{pH} 7.5)$ and membranes from control or CT-pretreated cells incubated in the absence or presence of activated CT $(100 \mu \mathrm{g} / \mathrm{ml}$; Tamir and Gill, 1988) with [ $\left.{ }^{32} \mathrm{P}\right]$ NAD under the conditions described by Klinz et al. (1987). [ $\left.{ }^{32} \mathrm{P}\right]$ ADP-ribosylated membrane proteins were analyzed by sodium dodecyl sulfate-polyacrylamide gel electrophoresis (SDS-PAGE; Laemmli, 1970) and visualized autoradiographically as previously described by Fisher and Heacock (1988). 
Radioligand binding

The binding of $\left[{ }^{3} \mathrm{H}\right] \mathrm{NMS}$ to mAChRs on intact SK-N-SH cells was determined as previously described by Fisher (1988).

\section{Data analysis}

Values quoted are means \pm SEM for the number of separate experiments stated in parentheses. Student's two-tailed $t$ tests were used to evaluate the statistical differences of the means of paired or unpaired sets of data. Percent inhibition of carbachol-stimulated ${ }^{3} \mathrm{H}$-IP release was calculated from the equation:

$$
\text { Percent inhibition }=\left[1-\frac{B-D}{A-C}\right] \times 100
$$

where $A$ is ${ }^{3} \mathrm{H}$-IP release observed in the presence of carbachol; $B$ is ${ }^{3} \mathrm{H}$-IP release observed in the presence of carbachol and inhibitory agent; $C$ is basal ${ }^{3} \mathrm{H}$-IP release observed in control incubations; and $D$ is basal ${ }^{3} \mathrm{H}$-IP release observed in control incubation containing the inhibitory agent. A negative value indicates that carbachol-stimulated ${ }^{3} \mathrm{H}$-IP release was higher in the presence of the agent than in its absence.

\section{RESULTS}

\section{Inhibition of carbachol-stimulated ${ }^{3} \mathrm{H}$-IP release by FSK}

Incubation of $\left[{ }^{3} \mathrm{H}\right]$ inositol-prelabeled SK-N-SH cells with $50 \mu M$ FSK, a diterpene that directly stimulates the catalytic subunit of adenylate cyclase (Seamon and Daly, 1986), resulted in a $41 \pm 4 \%$ inhibition of carbachol-stimulated ${ }^{3} \mathrm{H}-\mathrm{IP}$ release $(\mathrm{n}=16)$. Addition of FSK also inhibited the ability of carbachol to stimulate the labeling of the inositol lipid fraction $(33 \pm 4 \%$ inhibition, $n=11$ ), whereas no effect of FSK on basal lipid labeling was observed. The inhibitory effect of FSK was dose dependent with little effect detectable at $10 \mu M$ and maximum inhibition observed at $100 \mu M$ FSK, a concentration close to the solubility limit of FSK (Seamon and Daly, 1986) (Fig. 1). In all subse-

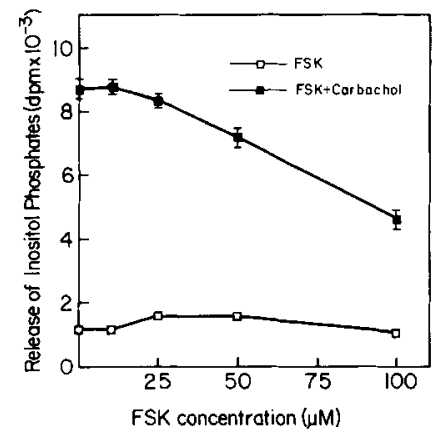

FIG. 1. Concentration dependence of FSK inhibition of stimulated ${ }^{3} \mathrm{H}-\mathrm{IP}$ release. Prelabeled SK-N-SH cells were incubated with increasing concentrations of FSK for $45 \mathrm{~min}$ at $37^{\circ} \mathrm{C}$ in the presence ( $\square$ ) or absence $(\square)$ of carbachol $(10 \mathrm{mM})$. Values shown are means \pm SEM for triplicate samples from a single experiment. Where error bars are not shown, they fall inside the symbol. In three or four separate experiments, the addition of $10,25,50$, and $100 \mu \mathrm{M}$ FSK resulted in $12 \pm 7,22 \pm 8,37 \pm 7$, and $66 \pm 6 \%$ inhibition of carbachol-stimulated ${ }^{3} \mathrm{H}$-IP release. Total inositol phosphate release was measured as described in Materials and Methods.

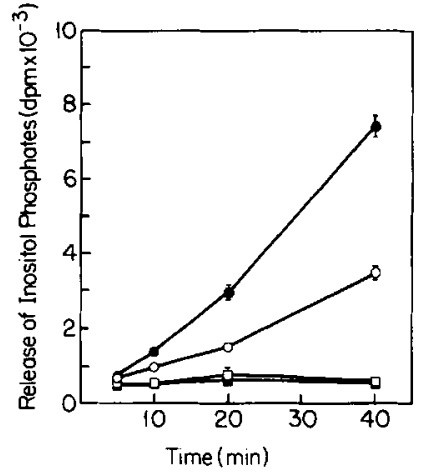

FIG. 2. Time course of FSK inhibition of carbachol-stimulated ${ }^{3} \mathrm{H}$ IP release. Prelabeled SK-N-SH cells were incubated for the des-

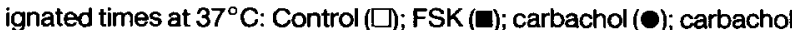
plus FSK $(O)$. Values shown are means \pm SEM for triplicate samples from a single experiment. In four separate time-course experiments, values for the percentage inhibition of carbachol-stimulated ${ }^{3} \mathrm{H}-\mathrm{IP}$ release obtained with $50 \mu M$ FSK at $5,10,20$, and $40 \mathrm{~min}$ of incubation were $24 \pm 16,54 \pm 8,34 \pm 9$, and $39 \pm 12$, respectively.

quent experiments, a concentration of $50 \mu M$ FSK was used. The inhibitory effects of FSK on carbachol-stimulated ${ }^{3} \mathrm{H}$-IP release were detectable within the first 5 $10 \mathrm{~min}$ of incubation, and persisted for up to at least $40 \mathrm{~min}$ (Fig. 2). Although FSK reduced the extent of carbachol-stimulated ${ }^{3} \mathrm{H}$-IP release, the concentration of agonist required to elicit a half-maximal increase in PPI turnover was not altered, indicating that FSK does not change the agonist's affinity for the mAChR (Fig. 3).

Because some of the effects of FSK have been previously ascribed to mechanisms that do not involve adenylate cyclase activation (Joost et al., 1988), additional experiments were conducted using either 7-O-

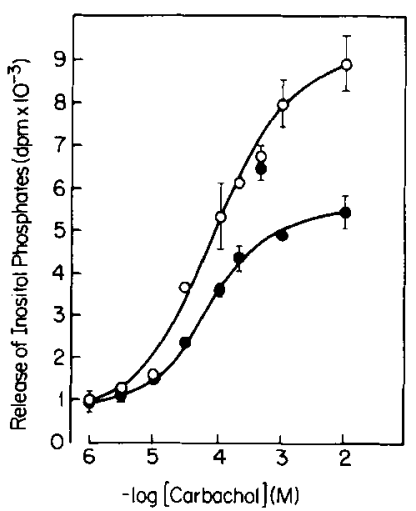

FIG. 3. Effect of FSK on dose dependence of carbachol-stimulated ${ }^{3} \mathrm{H}$-IP release. Cells were incubated with carbachol at the indicated concentrations in the absence $(O)$ or presence $(0)$ of $50 \mu M$ FSK. FSK did not alter basal ${ }^{3} \mathrm{H}-\mathrm{IP}$ release. Values shown are means \pm SEM for triplicate samples obtained from a single experiment. In the experiment shown, $\mathrm{EC}_{50}$ values for carbachol (calculated by log-probit analysis) were $80 \mu M$ (presence of FSK) and $120 \mu M$ (absence of FSK). In three separate experiments the mean values for the $\mathrm{EC}_{50}$ were $130 \pm 21 \mu \mathrm{M}$ (absence of FSK) and $177 \pm 73$ $\mu M$ (presence of FSK). 
TABLE 1. Effects of FSK and analogs on carbacholstimulated ${ }^{3} \mathrm{H}-\mathrm{IP}$ release and inositol lipid labeling

\begin{tabular}{lrr}
\hline & \multicolumn{2}{c}{ Inhibition (\%) } \\
\cline { 2 - 3 } Agent & \multicolumn{1}{c}{ IP } & Inositol lipids \\
\hline FSK, 50 $\mu M$ & $41 \pm 4(16)$ & $33 \pm 4(11)$ \\
7- $O$-Hemisuccinyl-7-deacetyl FSK, & & \\
$50 \mu M$ & $25 \pm 4(8)$ & $11 \pm 4(6)$ \\
1,9-Dideoxy FSK, 50 $\mu M$ & $5 \pm 8(5)$ & $2 \pm 8(5)$ \\
L-85,8051, 50 $\mu M$ & $27 \pm 8(3)$ & $20 \pm 8(3)$ \\
$200 \mu M$ & $56 \pm 6(3)$ & $25 \pm 8(3)$ \\
\hline
\end{tabular}

Cells were first prelabeled with $\left[{ }^{3} \mathrm{H}\right.$ ]inositol for $45 \mathrm{~min}$ and then incubated for an additional $45 \mathrm{~min}$ at $37^{\circ} \mathrm{C}$ with carbachol $(10 \mathrm{mM})$, in the presence or absence of the agent shown. $\mathrm{LiCl}(10 \mathrm{~m} M)$ was included in the assays during the incubation period to prevent the degradation of the primary IP formed, i.e.. IP ${ }_{1}$. Basal and stimulated ${ }^{3} \mathrm{H}$-IP release and inositol lipid labeling were determined as described in Materials and Methods. Values shown are percent inhibition of carbachol-stimulated ${ }^{3} \mathrm{H}$-IP release or inositol lipid labeling (means \pm SEM) or range $(n=2)$ for the number of separate experiments indicated in parentheses. Basal ${ }^{3} \mathrm{H}-\mathrm{IP}$ release and inositol lipid labeling were not affected by any of the agents listed.

hemisuccinyl-7-deacetyl FSK, an active structural analog of FSK (Pfeuffer and Metzger, 1982), L-85,8051, an active water-soluble FSK analog (Laurenza et al., 1987), or 1,9-dideoxy FSK, an inactive hydrophobic FSK analog (Laurenza et al., 1987). Addition of either 7-O-hemisuccinyl-7-deacetyl FSK or the water-soluble analog L-85,8051 significantly inhibited carbacholstimulated ${ }^{3} \mathrm{H}-\mathrm{IP}$ production (Table 1 ). In contrast, the addition of 1,9-dideoxy FSK had little or no effect on stimulated ${ }^{3} \mathrm{H}$-IP release (Table 1). It appears, therefore, that the ability of FSK to inhibit carbachol-stimulated PPI hydrolysis is mediated directly through its activation of adenylate cyclase and is not a function of its hydrophobicity.

\section{Inhibition of carbachol-stimulated ${ }^{3} \mathrm{H}$-IP release by IBMX, theophylline, and ABcAMP}

The addition of either IBMX or theophylline, both known inhibitors of cAMP phosphodiesterase, resulted in a $51-70 \%$ inhibition of carbachol-stimulated ${ }^{3} \mathrm{H}-\mathrm{IP}$ release, whereas basal IP release was unaffected (Table 2, part A). Similarly, these agents also inhibited carbachol-stimulated inositol lipid labeling, whereas no effect on basal lipid labeling was observed. When IBMX was included in incubations containing FSK, the resulting inhibition $(85 \pm 8, n=3)$ was less than additive $(p<0.05)$, a result indicative of a common site of action for these two agents. In contrast to the marked effects of inhibitors of cAMP phosphodiesterase on carbachol-stimulated ${ }^{3} \mathrm{H}-\mathrm{IP}$ release, direct addition of the cell permeant analog of CAMP, dBcAMP, at a concentration of $1 \mathrm{~m} M$ had only a modest inhibitory effect $(11 \%)$, the extent of which varied considerably between experiments (Table 2, part B). The direct addition of $8 \mathrm{BcGMP}$ was without effect.

\section{Effects of FSK and inhibitors of cAMP phosphodiesterase on ligand binding to mAChRs on SK-N-SH cells}

The inhibitory effects of FSK (and analogs), IBMX, or theophylline on mAChR-stimulated PPI turnover do not appear to be mediated through an inhibition of ligand binding to the $\mathrm{mAChR}$, because none of the agents tested had a significant effect on the binding of $\left[{ }^{3} \mathrm{H}\right] \mathrm{NMS}$ to binding sites on intact cells. Thus, in three separate experiments, specific $\left[{ }^{3} \mathrm{H}\right] \mathrm{NMS}$ binding in the presence of $50 \mu M$ concentrations of FSK, 1,9-dideoxy FSK, 7-O-hemisuccinyl-7-deacetyl FSK, or L-85,8051 was $100 \pm 0,97 \pm 2,97 \pm 3$, and $102 \pm 4 \%$ of control, respectively. $\left[{ }^{3} \mathrm{H}\right] N M S$ binding obtained in the presence of $1 \mathrm{~m} M$ IBMX or $2 \mathrm{~m} M$ theophylline was 99 \pm 6 and $94 \pm 4 \%$ of control, respectively.

\section{Intracellular cAMP concentrations}

The basal concentration of cAMP in SK-N-SH cells, measured under the same conditions as those employed for PPI turnover, was $24 \pm 2 \mathrm{pmol} / \mathrm{mg}$ protein (n $=12$ ). To establish whether cAMP intracellular concentrations were increased in the presence of FSK, IBMX, and theophylline, changes in the concentration of cAMP were measured. FSK $(50 \mu M)$ increased the concentration of cAMP to $281 \pm 62 \%$ of control (n =6), IBMX ( $1 \mathrm{~m} M)$ to $228 \pm 22 \%$ of control $(\mathrm{n}=10)$, and theophylline ( $2 \mathrm{mM}$ ) to $171 \pm 40 \%$ of control (n $=3$ ). cAMP could not be measured in the presence of $\mathrm{dBcAMP}$ or $8 \mathrm{BcGMP}$ because of cross-reactivity in the radioimmunoassay. Thus, the agents that inhibit stimulated PPI turnover also elicit a measurable increase in the concentration of cAMP in SK-N-SH cells.

\section{Inhibition of carbachol-stimulated ${ }^{3} \mathrm{H}$-IP release by $C T$}

$\mathrm{mAChR}$-stimulated PPI turnover was also inhibited by preincubation of SK-N-SH cells with CT, an agent known to activate adenylate cyclase through ADP-ribosylation of the $\alpha$-subunit of a stimulatory guanine nucleotide binding protein $\left(\mathrm{G}_{\mathrm{s}}\right.$; Gilman, 1987). Prein-

TABLE 2. Effects of (A) inhibitors of cAMP phosphodiesterase, (B) cell-permeant cyclic nucleotide analogs, and (C) CT on carbachol-stimulated ${ }^{3} \mathrm{H}-\mathrm{IP}$ release and inositol lipid labeling

\begin{tabular}{|c|c|c|}
\hline \multirow[b]{2}{*}{ Agent } & \multicolumn{2}{|c|}{ Inhibition $(\%)$} \\
\hline & IP & Inositol lipids \\
\hline \multicolumn{3}{|l|}{ (A) } \\
\hline IBMX, $1 \mathrm{~m} M$ & $51 \pm 3 \quad(15)$ & $23 \pm 5 \quad(12)$ \\
\hline $\begin{array}{l}\text { Theophylline, } 2 \mathrm{mM} \\
\text { (B) }\end{array}$ & $70 \pm 2(6)$ & $59 \pm 8$ \\
\hline dBcAMP, $1 \mathrm{mM}$ & $11 \pm 5 \quad(11)$ & $10 \pm 5$ \\
\hline $\begin{array}{l}\text { 8BcGMP. I } \mathrm{mM} \\
\text { (C) }\end{array}$ & $-12 \pm 3$ & $-2 \pm 2$ \\
\hline \multicolumn{3}{|l|}{ CT. $50 \mu \mathrm{g} / \mathrm{ml}$} \\
\hline $5 \mathrm{~h}$ & $45 \pm 10(3)$ & $42 \pm 11(2)$ \\
\hline $24 \mathrm{~h}$ & $37 \pm 4 \quad(7)$ & $33 \pm 4$ \\
\hline
\end{tabular}

See footnote to Table 1 for experimental details. 


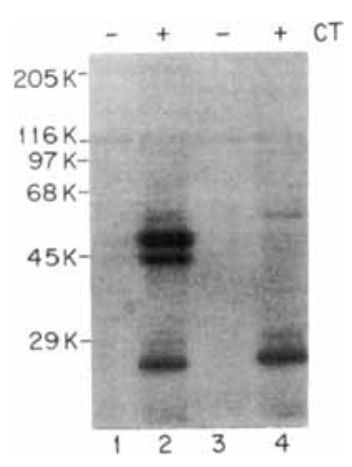

FIG. 4. $\left[{ }^{32} \mathrm{P}\right] A D P$-ribosylation of control or CT-pretreated cells by $\mathrm{CT}$. Intact $\mathrm{SK}-\mathrm{N}-\mathrm{SH}$ cells were pretreated in the absence or presence of CT $(50 \mu \mathrm{g} / \mathrm{ml})$ for $24 \mathrm{~h}$. Membrane preparations were then exposed to $\left.{ }^{32} \mathrm{P}\right] \mathrm{NAD}$ and activated CT for $30 \mathrm{~min}$, as described in Materials and Methods. Samples were then electrophoresed on SDSPAGE. Lanes 1 and 2 , control cells; lanes 3 and $4, C T$-pretreated cells. $+1-\mathrm{CT}$, membranes incubated in presence or absence of CT. Note the absence of labeling of the 42and 46-kilodalton bands in lane 4, indicating that previous ADP-ribosylation with endogenous NAD had occurred.

cubation of intact cells with CT $(50 \mu \mathrm{g} / \mathrm{ml})$ for either $5 \mathrm{~h}$ or $24 \mathrm{~h}$ inhibited carbachol-stimulated ${ }^{3} \mathrm{H}$-IP release by $37-45 \%$, whereas basal ${ }^{3} \mathrm{H}-\mathrm{IP}$ release remained unaffected. Carbachol-stimulated, but not basal, phospholipid labeling was also inhibited by $C T$ pretreatment (Table 2, part C). When IBMX $(1 \mathrm{~m} M)$ was added to CT-pretreated cells, there was a further increase in the inhibition of carbachol-stimulated ${ }^{3} \mathrm{H}$-IP release $(61$ $\pm 5 \%, \mathrm{n}=3$ ). However, the sum of CT- and IBMXmediated inhibitions was consistently found to be less than additive $(p<0.05)$. Preincubation of SK-N-SH cells with $\mathrm{CT}$ prevented the subsequent $\left.{ }^{32} \mathrm{P}\right] \mathrm{ADP}-\mathrm{ri}-$ bosylation of two membrane proteins of 42 and 46 kilodaltons (Fig. 4), indicating that ADP-ribosylation with endogenous NAD had occurred. Furthermore, in three separate experiments either a 5-h or 24-h pretreatment of SK-N-SH cells with CT reduced (by 84$89 \%$ ) the ability of $\mathrm{PGE}_{1}$ (an agonist that couples to adenylate cyclase activation through $\mathrm{G}_{\mathrm{s}}$ ) to increase cAMP concentration. Whereas a 5-h CT pretreatment increased cAMP concentration to $145-187 \%$ of control, this increase was not observed following a 24-h pretreatment $(112 \pm 10 \%$ of control, $\mathrm{n}=6)$. This may be attributable to an efflux of cAMP from cells that occurred during the prolonged incubation, as previously noted for bovine chromaffin cells (Chern et al., 1988).

\section{Inhibition of stimulated PPI turnover by cAMP in permeabilized cells}

To probe the site of action of CAMP on stimulated PPI turnover, digitonin-permeabilized SK-N-SH cells were employed. The addition of carbachol or GTP $\gamma \mathrm{S}$ to permeabilized cells elicited a large increase in the release of ${ }^{3} \mathrm{H}-\mathrm{IP}$, as previously observed (Fisher et al., 1989). Overnight preincubation with CT $(50 \mu \mathrm{g} / \mathrm{ml})$ or dBcAMP (1 $\mathrm{mM}$ ) prior to cell permeabilization reduced ${ }^{3} \mathrm{H}$-IP release elicited by carbachol, GTP $\gamma \mathrm{S}$, or their combination, whereas basal ${ }^{3} \mathrm{H}$-IP release was unaffected (Fig. 5). Although CT was markedly more effective than dBcAMP (28-73\% versus $15-44 \%)$, the ability of both agents to inhibit significantly GTP $\gamma$ Sstimulated ${ }^{3} \mathrm{H}-\mathrm{IP}$ release suggests that a primary site of action of cAMP occurs at or downstream from the $\mathrm{G}_{\mathrm{p}}-$ phospholipase $\mathrm{C}$ interaction. Because basal ${ }^{3} \mathrm{H}$-IP release was unaffected by pretreatment with $C T$ or dBcAMP, a direct action of cAMP on phospholipase $C$ activity appears unlikely. The ability of dBcAMP to inhibit PPI turnover in permeabilized cells following a 16-h incubation, in contrast to its relative ineffectiveness in short-term incubations (see Table 2, part B), suggests that it may not readily penetrate intact SK-N-SH cells.

In addition to its ability to increase the cAMP content of cells, CT is also known to inhibit stimulated PPI turnover through its interaction with a $G_{p}$ that mediates phospholipase $\mathrm{C}$ activation (Lo and Hughes, 1987; Schnefel et al., 1988). To evaluate this possibility, labeled SK-N-SH cells were first permeabilized, pretreated for 30-60 $\mathrm{min}$ in the absence or presence of 50 $\mu \mathrm{g} / \mathrm{ml}$ of activated CT, and then incubated with carbachol or GTP $\gamma S$ for another $15 \mathrm{~min}$. Preincubation with CT did not inhibit either carbachol- or GTP $\gamma$ Sstimulated ${ }^{3} \mathrm{H}$-IP release, even though ADP-ribosylation of membrane proteins was detected under these conditions. Thus, either $\mathrm{G}_{\mathrm{p}}$ in SK-N-SH cells is not a substrate for $\mathrm{CT}$, or alternatively, a more extensive incubation is necessary for ADP-ribosylation of $G_{p}$.

\section{Effect of the agonist $\mathrm{PGE}_{1}$ on carbachol-stimulated ${ }^{3} \mathrm{H}-\mathrm{IP}$ release}

The addition of agents that increase cAMP concentrations through mechanisms other than receptor activation results in an inhibition of $\mathrm{mAChR}$-stimulated PPI hydrolysis in SK-N-SH cells. To determine whether an increase in cAMP concentration elicited by the ad-

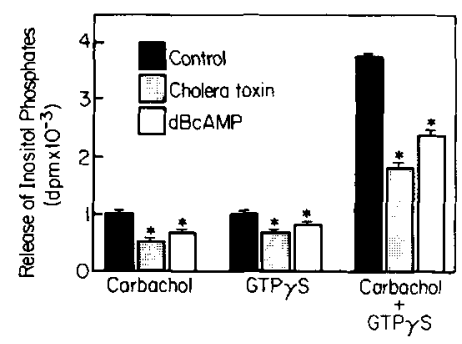

FIG. 5. Pretreatment with either $C T$ or $d B C A M P$ reduces the ability of both the agonist carbachol and GTP $\gamma \mathrm{S}$ to stimulate ${ }^{3} \mathrm{H}-\mathrm{IP}$ release from permeabilized SK-N-SH cells. Cells that had been prelabeled with $\left[{ }^{3} \mathrm{H}\right]$ inosiitol for 3 days were treated with either CT $(50 \mu \mathrm{g} /$ $\mathrm{ml}$ ), dBcAMP ( $1 \mathrm{mM}$ ), or buffer (control) for the last $16 \mathrm{~h}$ of labeling. Cells were then detached, permeabilized with digitonin, and incubated for $15 \mathrm{~min}$ at $37^{\circ} \mathrm{C}$ in the absence or presence of carbachol $(10 \mathrm{mM})$, GTP $\gamma \mathrm{S}(50 \mu \mathrm{M})$, or both. *Significantly different from control, $p<0.05$. Results shown are means \pm SEM for triplicate samples from a single experiment. Values for basal ${ }^{3} \mathrm{H}$-IP release in the experiment shown were $282 \pm 25,274 \pm 15$, and $276 \pm 14$ dpm for control, CT- and dBcAMP-pretreated cells, respectively. The concentration of $\mathrm{Ca}^{2+}$ was maintained at $60 \mathrm{nM}$ as previously described by Fisher et al. (1989). In three separate experiments pretreatment of SK-N-SH cells with $\mathrm{CT}$ reduced the carbachol, GTP $\gamma$ S, or carbachol plus GTP $\gamma$ S-stimulated release of ${ }^{3} \mathrm{H}-$ IP by $51 \pm 6,59 \pm 9$, and $47 \pm 9 \%$, respectively. The corresponding values obtained following pretreatment with dBCAMP were 27 $\pm 9,23 \pm 2$, and $26 \pm 7 \%$, respectively. 
dition of an agonist can produce a similar inhibition, the effect of $\mathrm{PGE}_{1}$ on carbachol-stimulated ${ }^{3} \mathrm{H}$-IP release was studied. Addition of $30 \mu M \mathrm{PGE}_{1}$ increased cAMP concentrations to $208 \pm 34 \%$ of control in the absence of $1 \mathrm{~m} M \operatorname{IBMX}(\mathrm{n}=3)$, and to $2,768 \pm 296 \%$ of control in the presence of IBMX $(n=9)$. These increases in cAMP concentration were not, however, accompanied by a significant inhibition of stimulated PPI turnover. Thus, the addition of $\mathrm{PGE}_{1}$ alone did not inhibit carbachol-stimulated ${ }^{3} \mathrm{H}$-IP release $(-5$ $\pm 9 \%, \mathrm{n}=5$ ), whereas in the presence of IBMX, PGE $_{1}$ addition resulted in a $57 \pm 6 \%$ inhibition $(\mathrm{n}=5)$, a value similar to that obtained for IBMX alone (51 $\pm 3 \%$, see Table 2, part A). $\mathrm{PGE}_{1}$ had no effect on basal ${ }^{3} \mathrm{H}$-IP release. Thus, $\mathrm{PGE}_{1}$-mediated increases in cAMP do not appear to result in an inhibition of stimulated PPI turnover.

\section{DISCUSSION}

The principal conclusion to emerge from the present study is that an increased intracellular concentration of cAMP elicited by agents that act at either the level of $\mathrm{G}_{\mathrm{s}}$, adenylate cyclase, or cAMP phosphodiesterase results in an inhibition of stimulated PPI turnover in SK-N-SH neuroblastoma. The evidence in favor of this conclusion is threefold. First, the addition of CT, an agent known to ADP-ribosylate the $\alpha$-subunit of $\mathrm{G}_{\mathrm{s}}$ and cause its permanent activation (Gilman, 1987), resulted in a marked inhibition of carbachol-stimulated ${ }^{3} \mathrm{H}$-IP release. Second, inclusion of either FSK, or its water-soluble analog, L-85,8051, both of which directly stimulate the catalytic unit of adenylate cyclase (Seamon and Daly, 1986; Laurenza et al., 1987), also resulted in an inhibition of stimulated inositol lipid hydrolysis. In contrast, the inactive analog of FSK, 1,9dideoxy FSK (Joost et al., 1988), had little or no effect on stimulated PPI turnover. Third, although relatively low resting levels of cAMP are present in SK-N-SH cells, inhibition of cAMP phosphodiesterase by inclusion of agents such as IBMX or theophylline resulted in increased cAMP concentrations and also inhibition of stimulated PPI turnover.

When SK-N-SH neuroblastomata were extensively pretreated with either CT or ABcAMP, the ability of either carbachol or GTP $\gamma \mathrm{S}$ to stimulate PPI turnover in digitonin-permeabilized cells was reduced to a similar extent (Fig. 5). This result indicates that the primary inhibitory site of action of CAMP resides either at or distal to the $G_{p}$-phospholipase $C$ interaction, rather than at the level of the mAChR or mAChR- $G_{p}$ coupling. cAMP has also recently been proposed to inhibit the activation of phospholipase $C$ by $G_{p}$ in platelets (Yada et al., 1989).

The ability of cAMP to inhibit stimulated PPI turnover has previously been observed for platelets (de Chaffoy de Courcelles et al., 1986), neutrophils (Takenawa et al., 1986; Della Bianca et al., 1986), kidney (Neylon and Summers, 1988), smooth muscle (Mad- ison and Brown, 1988), lymphocytes (Lerner et al., 1988), and adrenal glomerulosa cells (Guillon et al., 1988). In contrast, increases in cAMP concentration do not appear to inhibit stimulated PPI turnover in either hepatocytes (Kaibuchi et al., 1982) or in cerebral cortex (Hollingsworth and Daly, 1985). Despite the latter observation, our results with SK-N-SH cells (and recent observations with NG 108-15 cells; Campbell et al., 1988) suggest that inositol lipid hydrolysis may be subject to regulation by the cyclic nucleotide in at least some neural tissues.

Although inhibition of stimulated PPI turnover has been observed following receptor-mediated activation of adenylate cyclase (Kaibuchi et al., 1982; Della Bianca et al., 1986; de Chaffoy de Courcelles et al., 1986), most of the evidence implicating a regulatory role for CAMP in inositol lipid hydrolysis has been obtained from the use of agents that increase cAMP concentrations independently of receptor activation. An unexpected finding from the present study was that the increases in cAMP mediated by $\mathrm{PGE}_{1}$ (in contrast to those generated through receptor-independent mechanisms) were not accompanied by an inhibition of carbacholstimulated ${ }^{3} \mathrm{H}-\mathrm{IP}$ release in SK-N-SH cells, even though the intracellular concentrations of cAMP were increased by up to 28 -fold in the presence of the agonist. Conceivably, two explanations could account for this paradoxical result. First, it is possible that the rise in cAMP concentration and inhibition of stimulated PPI turnover observed in the presence of CT, IBMX, and FSK are parallel but unrelated events. For example, in addition to its known ability to inhibit cAMP phosphodiesterase, IBMX can block the inhibitory guanine nucleotide binding protein, $\mathrm{G}_{\mathrm{i}}$ (Parsons et al., 1988), and (like FSK) can directly inhibit the glucose transporter system in adipocytes (Kashiwagi et al., 1983). Although the possibility of such a direct inhibitory action of these agents on stimulated PPI turnover in SK$\mathrm{N}-\mathrm{SH}$ cells cannot be excluded, evidence in favor of an intermediary role for cAMP in the inhibition can be summarized as follows: (1) although CT, FSK, and IBMX have distinctly different proposed modes of action on the adenylate cyclase system, they affect cAMP content and stimulated PPI turnover in a similar manner; (2) when two of the agents are combined, e.g., CT and IBMX or FSK and IBMX, the resulting inhibition is less than additive, a result indicative of a common site of action for these agents; and (3) the specificity with which the FSK analogs inhibit PPI turnover mirrors their ability to activate adenylate cyclase. An alternative explanation for the inability of $\mathrm{PGE}_{1}$ to inhibit PPI turnover may lie in the compartmentation of cAMP within SK-N-SH neuroblastoma, such that the cellular concentration of cAMP attained in the presence of the agonist does not necessarily reflect its concentration in the biologically relevant compartment. Evidence to suggest the compartmentalization of both cAMP (and cAMP-dependent protein kinase) and inositol trisphosphate has been reported for a number of 
tissues (Spearman and Butcher, 1982; Merritt et al., 1986; Ambler et al., 1987). A further indication that separate metabolic compartments may exist for these two second messenger systems within the same cell was recently obtained from studies of tracheal smooth muscle. In these cells, agents that elevate cAMP result in an inhibition of histamine-stimulated PPI turnover, but not that mediated by mAChR activation (Madison and Brown, 1988). Although an explanation for the inability of $\mathrm{PGE}_{1}$ to inhibit carbachol-stimulated PPI turnover in SK-N-SH cells is not yet apparent, our results nonetheless stress the need to evaluate the effects of both receptor-mediated and -independent increases in cAMP when assessing the regulatory role of this cyclic nucleotide on inositol lipid hydrolysis.

The observation that increases in cAMP can inhibit stimulated PPI turnover in some tissues has led to speculation over the possible physiological significance of such a "cross-talk" between the two signaling mechanisms (Nishizuka, 1986; Jakobs et al., 1986). Although this remains an attractive hypothesis, two considerations are pertinent when evaluating this possibility in SK-N-SH cells. First, as previously noted, there are differential effects of increased cAMP concentrations on stimulated PPI turnover dependent on the agent employed. Second, in SK-N-SH cells the relationship between inositol lipid hydrolysis and adenylate cyclase may be additionally complex, because activation of the $\mathrm{M}_{3}$ mAChRs on these cells also results in a secondary increase in cAMP concentration (Baumgold and Fishman, 1988; Baron and Siegel, 1988). Thus, although it is evident that increases in cAMP mediated by the addition of certain agents can inhibit stimulated PPI turnover in SK-N-SH cells, the physiological significance of this inhibition remains to be determined.

In summary, the present results indicate that increases in cAMP concentration mediated by agents that act independently of receptor activation inhibit mAChR-stimulated PPI hydrolysis in human SK-N$\mathrm{SH}$ neuroblastoma cells. These results point to the possibility that stimulated inositol lipid hydrolysis may be similarly affected by cAMP in other neural preparations.

Acknowledgment: The authors wish to thank Dr. A. Heacock and Ms. Lisa Domask for their help with the SDS-PAGE and permeabilized cell experiments, and Ms. Jo Ann Kelsch for preparation of the manuscript. This work was supported by NIMH Grant MH 42652 .

\section{REFERENCES}

Akil M. and Fisher S. K. (1988) Inhibition of muscarinic receptor stimulated phosphoinositide turnover in SK-N-SH neuroblastoma cells by agents reported to increase intracellular cAMP. Soc. Neurosci. Abstr. 14, 228.

Ambler S. K., Thompson B., Solski P. A., Brown J. H., and Taylor P. (1987) Receptor-mediated inositol phosphate formation in relation to calcium mobilization: a comparison of two cell lines. Mol. Pharmacol. 32, 376-383.
Baron B. and Siegel B. W. (1988) Novel mechanisms of regulation of cyclic AMP in a neuroblastoma cell line. Soc. Neurosci. Abstr. $14,79$.

Baumgold J. and Fishman P. H. (1988) Muscarinic receptor mediated increase in cAMP levels in SK-N-SH human neuroblastoma cells. Biochem. Biophys. Res. Commun. 154, 1137-1143.

Campbell M. D., Subramanian S., Kotlikoff M. I., Williamson J. R. and Fluharty S. J. (1988) cAMP modulates inositol polyphosphate production and calcium mobilization in NG108-15 cells. Soc. Neurosci. Abstr. 14, 81.

Chern Y. J., Kim K. T., Slakey L. L., and Westhead E. W. (1988) Adenosine receptors activate adenylate cyclase and enhance secretion from bovine adrenal chromaffin cells in the presence of forskolin. J. Neurochem. 50, 1484-1493.

de Chaffoy de Courcelles D., Roevens P., and van Belle H. (1986) Agents that elevate platelet cAMP stimulate the formation of phosphatidylinositol 4-phosphate in intact human platelets. FEBS Lett. 195, 115-118.

Della Bianca V., De Togni P., Grzeskowiak M., Vicentini L. M., and Di Virgilio F. (1986) Cyclic AMP inhibition of phosphoinositide turnover in human neutrophils. Biochim. Biophys. Acta 886, 441-447.

Fisher S. K. (1988) Recognition of muscarinic cholinergic receptors in human SK-N-SH neuroblastoma cells by quaternary and tertiary ligands is dependent upon temperature, cell integrity, and the presence of agonists. Mol. Pharmacol. 33, 414-422.

Fisher S. K. and Bartus R. T. (1985) Regional differences in the coupling of muscarinic receptors to inositol phospholipid hydrolysis in guinea pig brain, J. Neurochem. 45, 1085-1095.

Fisher S. K. and Heacock A. M. (1988) A putative $M_{3}$ muscarinic cholinergic receptor of high molecular weight couples of phosphoinositide hydrolysis in human SK-N-SH neuroblastoma cells. J. Neurochem. 50, 984-987.

Fisher S. K. and Snider R. M. (1987) Differential receptor occupancy requirements for muscarinic cholinergic stimulation of inositol lipid hydrolysis in brain and in neuroblastomas. Mol. Pharmacol. 32, 81-90.

Fisher S. K., Domask L. M., and Roland R. (1989) Muscarinic receptor regulation of cytoplasmic $\mathrm{Ca}^{2+}$ concentrations in human SK-N-SH neuroblastoma cells: $\mathrm{Ca}^{2+}$ requirements for phospholipase C activation. Mol. Pharmacol. 35, 195-204.

Geiger P. J. and Bessman S. P. (1972) Protein determination by Lowry's method in the presence of sulfhydryl reagents. Anal. Biochem. 49, 467-473.

Gilman A. G. (1987) G-proteins; transducers of receptor-generated signals. Annu. Rev. Biochem. 56, 615-649.

Guillon G., Gallo-Payet N., Balestre M.-N., and Lombard C. (1988) Cholera toxin and corticotropin modulation of inositol phosphate accumulation induced by vasopressin and angiotensin II in rat glomerulosa celis. Biochem. J. 253, 765-775.

Hollingsworth E. B. and Daly J. W. (1985) Accumulation of inositol phosphates and cyclic AMP in guinea pig cerebral cortical preparations. Effects of norepinephrine, histamine, carbamylcholine and 2-chloroadenosine. Biochim. Biophys. Acta 847, 207-216.

Honegger P. and Richelson E. (1976) Biochemical differentiation of mechanically dissociated mammalian brain in aggregating cell culture. Brain Res. 109, 335-354.

Jakobs K. H., Watanabe Y., and Bauer S. (1986) Interactions between the hormone sensitive adenylate cyclase system and the phosphoinositide-metabolizing pathway in human platelets. $J$. Cardiovasc. Pharmacol. 8, S61-S64.

Joost H. G., Habberfield A. D., Simpson I. A., Laurenza A., and Seamon K. B. (1988) Activation of adenylate cyclase and inhibition of glucose transpon in rat adipocytes by forskolin analogues: structural determinants for distinct sites of action. $\mathrm{Mol}$. Pharmacol. 33, 449-453.

Kaibuchi K., Takai Y., Ogawa Y., Kimura S., and Nishizuka Y. (1982) Inhibitory action of adenosine 3 ',5'-monophosphate on phosphatidylinositol turnover: difference in tissue response. Biochem. Biophys. Res. Commun. 104, 105-112. 
Kashiwagi A., Huecksteadt T. P., and Foley J. E. (1983) The regulation of glucose transport by cAMP stimulators via three different mechanisms in rat and human adipocytes. J. Biol. Chem. 258, 13685-13692.

Kato H., Ishitoya J., and Takenawa T. (1986) Inhibition of inositol phospholipids metabolism and calcium mobilization by cyclic AMP-increasing agents and phorbol ester in neutrophils. Biochem. Biophys. Res. Commun. 139, 1272-1278.

Klinz F.-J., Yu V. C., Sadee W., and Costa T. (1987) Differential expression of $\alpha$-subunits of G-proteins in human neuroblastomaderived cell clones. FEBS Lett. 224, 43-48.

Laemmli U. K. (1970) Cleavage of structural proteins during the assembly of the head of bacteriophage T4. Nature 227, 680685 .

Laurenza A., Khandelwal Y., De Souza N. J., Rupp R. H., Metzger H., and Seamon K. B. (1987) Stimulation of adenylate cyclase by water-soluble analogues of forskolin. Mol. Pharmacol. 32, 133-139.

Lerner A., Jacobson B., and Miller R. A. (1988) Cyclic AMP concentrations modulate both calcium flux and hydrolysis of phosphatidylinositol phosphates in mouse T lymphocytes. $J$. $\mathrm{Jm}$ munol. 140, 936-940.

Lo W. W. Y. and Hughes J. (1987) A novel cholera toxin-sensitive G-protein $\left(G_{c}\right)$ regulating receptor-mediated phosphoinositide signalling in human pituitary clonal cells. FEBS Lett. 220, 327331 .

Madison J. M. and Brown J. K. (1988) Differential inhibitory effects of forskolin, isoproterenol, and dibutyryl cyclic adenosine monophosphate on phosphoinositide hydrolysis in canine tracheal smooth muscle. J. Clin. Invest. 82, 1462-1465.

Merritt J. E., Taylor C. W., Rubin R. P., and Putney J. W., Jr. (1986) Isomers of inositol trisphosphate in exocrine pancreas. Biochem. $J, 238,825-829$.

Neylon C. B. and Summers R. J. (1988) Inhibition by cAMP of the phosphoinositide response to $\alpha_{1}$-adrenoceptor stimulation in rat kidney. Eur. J. Pharmacol. 148, 441-444.
Nishizuka Y. (1986) Studies and perspectives of protein kinase C. Science 233, 305-312.

Parsons W. J., Ramkumar V., and Stiles G. L. (1988) Isobutylmethylxanthine stimulates adenylate cyclase by blocking the inhibitory regulatory protein, $\mathrm{G}_{\mathrm{i}}$. Mol. Pharmacol. 34, 37-41.

Pfeuffer T. and Metzger H. (1982) 7-O-Hemisuccinyl-deacetyl forskolin-Sepharose: a novel affinity support for purification of adenylate cyclase. FEBS Lett. 146, 369-375.

Schnefel S., Banfic H., Eckhardt L., Schultz G., and Schultz I. (1988) Acetylcholine and cholecystokinin receptors functionally couple by different $\mathrm{G}$-proteins to phospholipase $\mathrm{C}$ in pancreatic acinar cells. FEBS Lett. 230, 125-130.

Seamon K. B. and Daly J. W. (1986) Forskolin, cyclic AMP and cellular physiology. Adv. Cyclic Nucleotide Protein Phosphorylation Res. 20, 1-150.

Spearman T. and Butcher F. R. (1982) Rat parotid gland protein kinase activation. Relationship to enzyme secretion. Mol. Pharmacol. 21, 121-127.

Takenawa T., Ishitoya J., and Nagai Y. (1986) Inhibitory effect of prostaglandin $E_{2}$, forskolin, and dibutyryl cAMP on arachidonic acid release and inositol phospholipid metabolism in guinea pig neutrophils. J. Biol. Chem. 261, 1092-1098.

Tamir A. and Gill D. M. (1988) ADP-ribosylation by cholera toxin of membranes derived from brain modifies the interaction of adenylate cyclase with guanine nucleotides and $\mathrm{NaF}$. J. Neurochem. 50, 1791-1797.

Yada Y., Nagao S., Okano Y., and Nozawa Y. (1989) Inhibition by cyclic AMP of guanine nucleotide-induced activation of phosphoinositide-specific phospholipase $\mathrm{C}$ in human platelets. FEBS Lett. 242, 368-372.

Yu V. C., Richard M. L., and Sadee W. (1986) A human neuroblastoma cell line expresses $\mu$ and $\delta$ opioid receptor sites. J. Biol Chem. 261, 1065-1070.

Yu V. C., Hochhaus G., Chang F.-H., Richard M. L., Bourne H. R., and Sadee W. (1988) Differentiation of human neuroblastoma cells: marked potentiation of prostaglandin E-stimulated accumulation of cyclic AMP by retinoic acid. J. Neurochem. 51, 1892-1899. 